\title{
Evaluating the impacts of visitation on vegetation associated with waterfalls in Tijuca National Park (RJ, Brazil)
}

\section{Avaliação de impactos da visitação na vegetação associada a cachoeiras no Parque Nacional da Tijuca (RJ)}

\author{
Inés Gómez Menéndez, André Scarambone Zaú, Richieri Antônio Sartori ${ }^{1}$
}

\begin{abstract}
The Tijuca National Park is considered to be the world's second largest urban forest, and was contemplated by the first project project for the recuperation of degraded habitats in Brazil. As it is located in the center of Brazil's second-largest city, Rio de Janeiro, Tijuca National Park is also a popular attraction for both tourists and residents, and includes features such as scenic lookouts, waterfalls, and trails. In 2014, a research program was initiated to evaluate anthropogenic impacts on biological communities located in the vicinity of the waterfalls in which visitors bathe. In this context, the present study evaluated the impacts on the vegetation, with the aim of providing park administrators with guidelines for the regulation and management of these leisure activities. The study focused on the waterfalls located upstream from the Baronesa Bridge, and the impacts on the local shrubby/arboreal-regenerative stratum. Data were collected in 10 plots of $10 \mathrm{~m} \times 2.5 \mathrm{~m}$, located in the vicinity of the river, for comparison with an additional 10 plots located at a distance of $30 \mathrm{~m}$ from the river, in areas that suffer less direct impact from visitation. A number of parameters were compared between the sets of plots, including indices of diversity and evenness, mean height, basal area, density, and the presence of tillers, and exotic and endangered species, the edaphic conditions, proportion of individuals with regrowth tillers, proportion of individuals from exotic and endareged species, soil exposure and slope. The data were analyzed using both univariate (Student's $t$, Mann-Whitney's "U") and multivariate (NMDS, Cluster Analysis, ANOSIM and NPMANOVA) procedures. The results indicated that the composition of the vegetation varied significantly between environments, with a lower diversity and greater structural homogeneity being found closer to the river. This indicates the simplification of the plant community in this environment, which was interpreted as evidence of degradation caused directly by visitors. Soil exposure and the proportion of regrowth tillers (possibly resulting from the systematic breaking of saplings) in the plots adjacent to the river are two indicators that were found to be associated with the presence of visitors at the waterfall.
\end{abstract}

KEYWORDS: Visitation Management; Anthropogenic Impact; Protected Areas. 


\section{RESUMO}

O Parque Nacional da Tijuca é considerado a segunda maior floresta urbana do mundo, na qual ocorreram os primeiros projetos de recuperação de áreas degradadas do Brasil. Por conta de estar localizada no centro da segunda maior cidade brasileira, o Rio de Janeiro, é também uma atração para turistas e residentes, com muitas cachoeiras e trilhas. Em 2014 foi iniciado no Parque um conjunto de pesquisas para avaliar impactos antrópicos sobre diversas comunidades biológicas em uma área de quedas d'água, utilizadas para banho pelos visitantes. O objetivo deste trabalho foi avaliar e auxiliar na decisão da administração do Parque de manejar essa atividade nas cachoeiras situadas à montante da Ponte da Baronesa, entre elas a Cascata da Gruta, a Cachoeira da Gabriela e a Cachoeira da Diamantina, avaliando impactos sobre o estrato arbustivo/arbóreo-regenerante. Alocamos 10 parcelas de 10×2,5m no entorno do rio: a priori com influência antrópica direta; e 10 parcelas distantes $30 \mathrm{~m}$ dessas: em tese trechos menos sujeitos ao impacto direto da visitação. Foram calculados indicadores de diversidade (riqueza observada, esperada e equabilidade), fitossociologia (Índice de Valor de Importância, considerando densidade, dominância e frequência), estrutura da vegetação (altura média, área basal, densidade de indivíduos, proporção de indivíduos com múltiplos perfilhos, proporção de indivíduos de espécies exóticas, proporção de indivíduos de espécies ameaçadas) e condições edáficas (proporção de solo exposto e declividade). Foram realizadas comparações estatísticas univariadas através dos testes de "t" de Student e "U" de Mann Whitney, e multivariadas (NMDS, Análise de Agrupamento, ANOSIM e NPMANOVA). Os resultados apontaram composição florística distinta nos dois ambientes, com menor diversidade e maior homogeneidade estrutural na vegetação imediatamente às margens do rio. Levantamos a hipótese de simplificação da comunidade vegetal neste contexto, sendo esse fato interpretado como um indicativo de degradação antrópica. A exposição do solo e a proporção de indivíduos perfilhados (possível resultado de quebra sistemática de galhos e arvoretas), significativamente maiores no entorno do rio, foram apontados como impactos associados ao trânsito de visitantes.

PALAVRAS-CHAVE: Gestão da Visitação; Impacto Antrópico; Unidades de Conservação.

\section{Introduction}

In recent years, tourism in natural areas has been growing at an everincreasing rate (DOUROJEANNI; PÁDUA, 2007). Tourism and leisure activities, such as bathing at waterfalls, are among the principal objectives of visitors to national parks, in particular those with good access and facilities (ZAÚ, 2014). From an ecological and conservation perspective, however, research on the potential negative impacts of these activities is still incipient (ZAÚ, op. cit.). In fact, considerable lacunas exist in the scientific understanding of the impacts of the use of tropical waterfalls, in particular in the Brazilian Atlantic Forest, in relation to the support capacity (the environmental sustainability of visitation), and the possible negative ecological effects of these activities (ABELLAN, 1998; GÓMEZ-LIMÓN; DE LUCIO, 1995; MELO; DURIGAN, 2007). In this context, innovative approaches that contribute to the conservation of the biodiversity of protected areas are essential for the development of more adequate strategies for the management of conservation units open to visitation. 
The Tijuca National Park is one of the world's largest parks located entirely within an urban matrix (ZAÚ, 2015). While Tijuca is the smallest of Brazil's 72 national parks (ICMBio, 2017), with an area of approximately four thousand hectares, it receives the most visitors, with more than three million recorded in 2014 (ICMBio, 2015). In 2014, a research program was initiated in the park to evaluate the conservation status of a stretch of the Archer River which encompasses the Gruta Cascade, and the Gabriela and Diamantina waterfalls. The area is frequented by park visitors, who bathe in the river, despite this use is not approved in the park's management plan (ICMBio, 2008). This research program was designed to provide guidelines for an official decision on the possible authorization of the use of the area for bathing. Park administrators, the scientific community, regular visitors, and environmental bodies all expected the research to provide a conclusive perspective on this question. It was also hoped that a more detailed evaluation of the evolution of the conservation status and the degradation of the area would provide valuable insights for the development of effective management proposals for the conservation of the area.

This study presents the principal results of the analysis of the conservation status of the vegetation of the study area (GÓMEZ MENÉNDEZ, 2016), and represents the starting point of the measurement of the eventual impacts that would result from the regularization of the recreational use of the area. The principal objective of this study was to evaluate the physical and phytosociological structure of the shrubby/arboreal-regenerative stratum of the vegetation adjacent to the waterfalls upstream from the Baronesa Bridge, that is, the Gruta Cascade, and the Gabriela and Diamantina waterfalls, and relate this status to the direct impacts resulting from the access of visitors. The specific objectives included the evaluation and comparison of indices of plant diversity and composition, the structure of the vegetation, and the soil exposure. This study tested the following question: do significant differences exist in the ecological indices that determine the conservation status of the study area that are consistent with the anthropogenic disturbance of the riparian vegetation? In this context, the conservation status of the vegetation can be evaluated reliably based on a number of ecological indices, including diversity (BARLOW et al., 2007), the distribution and abundance of species (CAMPBELL, 1994), growth parameters (GÓMEZ-LIMÓN; GARCíA VENTURA, 2014), and soil exposure rates (ABELLAN, 1998).

\section{Material and Methods}

The study area is located in sector A - "Floresta da Tijuca" of the Tijuca National Park, in the valley of the Archer River, near Baronesa Bridge. The national park is located on steep hillsides covered with dense, submontane rainforest (sensu VELOSO; RANGEL FILHO; LIMA, 1991; Figure 1). 


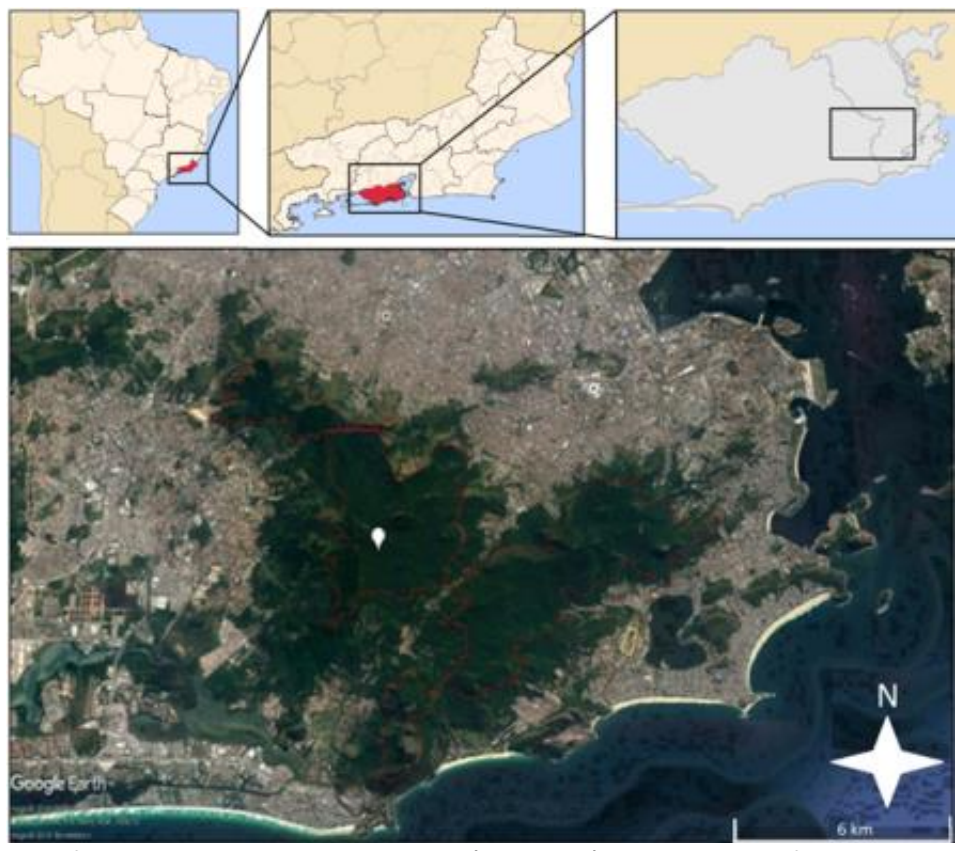

Figure 1: Limits of the Tijuca National Park (red line) in the city of Rio de Janeiro, and the study area (white marker). Tijuca National Park, Rio de Janeiro, RJ. 2015.

Figura 1: Limites do Parque Nacional da Tijuca (linha vermelha) na cidade do Rio de Janeiro, e a área de estudo (marcador branco). Parque Nacional da Tijuca, Rio de Janeiro, RJ. 2015.

The vegetation was sampled in $202.5 \mathrm{~m} \times 10 \mathrm{~m}$ plots, with a total area of $500 \mathrm{~m} 2$, distributed within an area of approximately $1.64 \mathrm{ha}$, at altitudes of between $590 \mathrm{~m}$ and $657 \mathrm{~m}$ above sea level (Figure 2). Half (10) of these plots were located in the vicinity of the waterfalls, arranged to avoid the presence of trails or rocky outcrops. These plots constituted the Waterfall Sample (WS), which was assumed to represent the vegetation most exposed to anthropogenic impact derived from the visitation of the waterfalls.

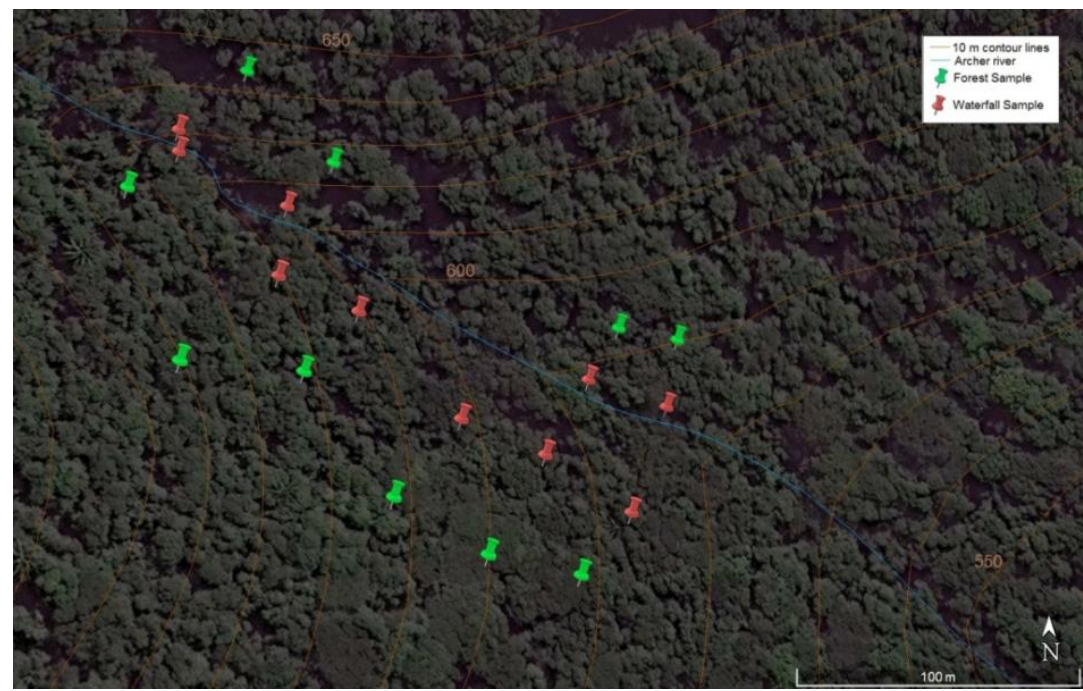

Figure 2: Location of the study plots in the Tijuca forest, Rio de Janeiro, used to analyze the environmental impacts caused by visitors to the local waterfalls. Source: Google Earth, 2015.

Figura 2: Localização das parcelas de estudo na Floresta da Tijuca, Rio de Janeiro, usadas para analisar os impactos antrópicos associados à visitação das cachoeiras.

Fonte: Google Earth, 2015. 
The other 10 plots form the Forest Sample (FS). These plots were paired with the WS plots, but were located at a distance of $30 \mathrm{~m}$ from their corresponding WS plots, in a perpendicular direction from the body of water. The FS plots were assumed to be less impacted by visitor access to the waterfalls and river, due to their greater distance from these sites, and their relative inaccessibility. The shrubby/arboreal-regenerative stratum of each plot was inventoried systematically, with the diameter at ground level (DGL) of each plant $(1 \mathrm{~cm}<D G L<5 \mathrm{~cm})$ and its height $(\mathrm{m})$ being measured, following standard procedures (SYLVESTRE; ROSA, 2002). In each plot, the percentage of soil exposed was estimated at 10 points, selected randomly, using a $0.5 \mathrm{~m} \times 0.5 \mathrm{~m}$ quadrat. The mean slope of each plot was also measured.

The differences between the two sets of plots, adjacent to (WS) and distant from (FS) the waterfalls, were evaluated using the following indices:

a) Plant composition and phytosociology: observed species richness (Margalef and Menhinick), diversity and evenness (Simpson, ShannonWiener, modified Shannon-Wiener, and Brillouin), species richness estimated by the nonparametric Chao-2 procedure (MAGURRAN, 2004), and the parametric Clench curve (JIMENEZ-VALVERDE; HORTAL, 2003). The Importance Value Index (IVI) was calculated for each sample (WS and FS), considering the dominance, frequency, and density of each species. Subsequently, the 10 species in each area with the highest IVI values were evaluated and classified in terms of: (i) successional class: Pioneer (Pi), Early successional (Es), and late successional/climax, Ls (modified from BUDOWSKI, 1965); (ii) the amplitude of the geographic distribution of the species in Brazilian biomes (JBRJ, 2010; OLIVEIRA-FILHO; FONTES, 2000), and (iii) the rarity of the species in the Atlantic Forest domain (OLIVEIRA-FILHO; FONTES, 2000; CAIAFA; MARTINS, 2010). The similarities between the samples were also assessed using the Jaccard and Sörensen indices, and multivariate analyses.

b) Physical structure of the shrubby/arboreal-regenerative stratum and edaphic conditions: the following parameters were calculated for each plot - mean height (h), basal area (BA), individual density (D), the proportion of individuals with multiple regrowth tillers (\%T), the percentage of individuals belonging to exotic species (\%Ex), percentage of individuals belonging to endangered species (\%En), percentage of soil exposed (\%ES), and slope (\%Slo). Preliminary analyses consisted of the calculation of the mean, coefficient of variation, amplitude, minimum and maximum values, to characterize the physical structure of the vegetation of the two samples (WS, FS), and the soil exposure in the plots. The normality of each variable was then assessed using the D'Angostino, Lilliefors and Shapiro-Wilks tests, while homocedasticity was evaluated using the Snedecor and Cochran tests (GRAPHPAD PRISM, 2015). The differences between the samples were then tested using the $t$ test for parametric and 
homoscedastic variables, and Mann-Whitney's $U$ for nonparametric data.

To evaluate general patterns in the parameters analyzed, multivariate plots (cluster analysis and non-metric multidimensional scaling, NMDS) and numerical analyses (ANOSIM and NPMANOVA) were applied to the combined indices (GRAPHPAD PRISM, 2015; HAMMER et al. 2001), including the species composition (occurrence of species in the plots), structural indices (h, $\mathrm{BA}, \mathrm{D}, \% \mathrm{~T}$ ), all the indices of plant development (h, BA, \%M, D, \%Ex, \%En), all vegetation variables (occurrence of species, $h, B A, \% M, D, \% E x, \% E n$ ), physical parameters (\%ES, \%Slo), and all variables combined. The procedures followed the approach adopted by Zaú $(2010 ; 2014 b)$ and Machado (2012).

\section{Results and Discussion}

The vegetation of the FS plots was more diverse $(\mathrm{H}=3.6)$ than the WS plots $(H=3.1)$, and all other indices presented higher values for the forest plots (Table 1). The estimators of species richness (Clench and Chao-2 curves) also indicated that a more comprehensive inventory of the vegetation of the study area would have identified a species richness in the FS (66 species expected) almost double that of the WS (35 species expected).

Table 1: Indices of a diversity for the WS and FS plots in Tijuca National Park. $\mathrm{N}=$ number of individuals, Sobs = number of species, DMG = Margalef's index, DMH = Mehnick's index, SiD = Simpson's index, $\mathrm{H}$ = Shannon-Wiener index, $\mathrm{H}^{\prime}=$ modified Shannon-Wiener index, $\mathrm{HB}=$ Brillouin's index. Tijuca National Park, Rio de Janeiro, Brazil. 2015.

Tabela 1: Índices de diversidade a para as parcelas WS e FS no Parque Nacional da Tijuca. $\mathrm{N}$ = número de indivíduos, Sobs: número de espécies, DMG = Índice de Margalef, DMH = Índice de Menhinick, SiD = Índice de Simpson, $\mathrm{H}$ = Índice de Shannon-Wienner, H'= Índice de

Shannon-Wienner modificado, HB = Índice de Brillouin. Parque Nacional da Tijuca, Rio de Janeiro, RJ. 2015.

\begin{tabular}{|c|c|c|c|c|c|c|c|c|}
\hline & $\mathbf{N}$ & Sobs & DMG & DMH & SiD & H & $H^{\prime}$ & HB \\
\hline wS & 82 & 30 & 6.58 & 3.31 & 0.94 & 3.10 & 22.09 & 2.64 \\
\hline FS & 105 & 49 & 10.31 & 4.78 & 0.95 & 3.55 & 34.82 & 3.00 \\
\hline TOTAL & 187 & 72 & 13.57 & 5.27 & 0.96 & 3.81 & 45.12 & 3.33 \\
\hline
\end{tabular}

The classification of the species by the IVI identified the 10 species with the highest frequency, density, and abundance in the two samples. While these species varied between samples, they were all early or late successional (BUDOWSKI, 1965), with an ample geographic distribution (OLIVEIRA-FILHO; FONTES, 2000; JBRJ 2010), and were common in the Atlantic Forest (OLIVEIRA-FILHO; FONTES, 2000; CAIAFA; MARTINS, 
2010). The similarity in the composition of the vegetation in the two samples was very low (Jaccard index $=0.09$; Sorensen index $=0.17$ ). This indicates that the composition of the communities in the two areas (forest and waterfall) was quite distinct.

The structural parameters indicated that the vegetation was more welldeveloped in the forest plots (FS) in comparison with the waterfall (WS) plots (Table 2, next page). In the FS plots, the vegetation was almost a half-meter taller, on average, than in the WS plots, mean basal area was almost double (Figure 3), and the density of individuals was $20 \%$ greater. By contrast, the percentage of individuals with multiple regrowth tillers was $67 \%$ higher in the WS plots (Figure 4) in comparison with the FS, which can be interpreted as a response of individuals capable of resprouting to the breaking of trunks and branches, whether accidental or otherwise, by visitors making their way to and from the waterfalls. The percentage of individuals of exotic species did not vary significantly between samples, given that only a single coffee plant (Coffea arabica) was recorded in the FS. The percentage of individuals of threatened species was also similar in the two samples, despite the fact that twice as many species (6) were recorded in the FS in comparison with the WS (3). This difference suggests that some endangered species may have been excluded from the vicinity of the waterfalls, although the difference was not significant.

Important differences were also noted in the physical parameters of the respective study plots, which may indicate the impact of the recreational use of the area. While the WS plots were less sloped than the FS plots, they contained a higher percentage of soil exposed, with much more variable values than those recorded in the FS plots. This indicates a reduction in the leaf litter that would normally be covering the ground in these areas, which would probably be at least partly related, once again, to the movements of visitors on the local trails and in the vicinity of the waterfalls. The statistical analyses ( $t$ and $U$ tests) indicated significant differences between WS and FS plots in basal area, percentage of individuals with multiple regrowth tillers, slope and soil exposed (Figure 3, next page).

The multivariate plot of structural parameters (Figure 4, next page) showed a higher concentration in the morphological variables of the vegetation in the WS sample, which indicates a greater structural homogeneity in this sample. In the analyses of species composition (Figure 5, next page) and physical parameters (Figure 6, next page), the two samples were differentiated clearly. The results of the ANOSIM and NPMANOVA confirm the existence of significant differences between the two samples (WS and FS) in species composition and physical parameters (Table 3, next page). 
Table 2. Results of the ANOSIM and NPMANOVA tests for the combinations of the indices analyzed. Significant differences $(p<0.05)$ between samples (WS and FS) are highlighted in bold type. Tijuca National Park, Rio de Janeiro, RJ. 2015.

Tabela 2. Resultados dos testes ANOSIM e NPMANOVA para as combinações de indicadores analisados. Diferenças significativas $(p<0.05)$ entre os conjuntos (WS e FS) são marcadas em negrito. Parque Nacional da Tijuca, Rio de Janeiro, RJ. 2015.

\begin{tabular}{|c|c|c|c|c|c|c|}
\hline $\begin{array}{l}\text { Index } \\
\text { Analysis } \\
\text { (Method) }\end{array}$ & \multicolumn{2}{|c|}{$\begin{array}{l}\text { Cluster } \\
\text { (Bray-Curtis } \\
\text { distance) }\end{array}$} & \multicolumn{2}{|c|}{$\begin{array}{c}\text { NMDS } \\
\text { (Euclidian distance) }\end{array}$} & \multicolumn{2}{|c|}{$\begin{array}{l}\text { Cluster and NMDS } \\
\text { (Euclidian distance) }\end{array}$} \\
\hline \multirow{2}{*}{ ANOSIM } & $\mathrm{R}$ & 0.9793 & $\mathrm{R}$ & 0.8620 & $\mathrm{R}$ & 0.2008 \\
\hline & $p$ & 0.0001 & $\mathrm{p}$ & 0.0002 & $p$ & 0.0001 \\
\hline \multirow{2}{*}{ NPMANOVA } & $\mathrm{F}$ & 62.780 & $\mathrm{~F}$ & 51.600 & $\mathrm{~F}$ & 3.501 \\
\hline & $p$ & 0.0001 & $\mathrm{p}$ & 0.0001 & $\mathrm{p}$ & 0.0001 \\
\hline Index & \multicolumn{4}{|c|}{ MORPHO-STRUCTURAL INDICES } & \multirow{2}{*}{\multicolumn{2}{|c|}{$\begin{array}{c}\text { ALL VEGETATION VARIABLES } \\
\text { Cluster and NMDS } \\
\text { (Bray-Curtis distance) }\end{array}$}} \\
\hline $\begin{array}{l}\text { Analysis } \\
\text { (Method) }\end{array}$ & \multicolumn{2}{|c|}{$\begin{array}{c}\text { Cluster } \\
\text { (Jaccard coefficient) }\end{array}$} & \multicolumn{2}{|c|}{$\begin{array}{c}\text { NMDS } \\
\text { (Euclidian distance) }\end{array}$} & & \\
\hline \multirow{2}{*}{ ANOSIM } & $\mathrm{R}$ & 0.02222 & $\mathrm{R}$ & 0.0980 & & 0.0513 \\
\hline & $\mathrm{p}$ & 0.4662 & $\mathrm{p}$ & 0.0960 & & 0.1747 \\
\hline \multirow{2}{*}{ NPMANOVA } & $\mathrm{F}$ & 1.6100 & $\mathrm{~F}$ & 1.8190 & & 1.6150 \\
\hline & $p$ & 0.2126 & $\mathrm{p}$ & 0.1640 & & 0.2103 \\
\hline Index & \multicolumn{4}{|c|}{ ALL DEVELOPMENT INDICES } & \multirow{2}{*}{\multicolumn{2}{|c|}{$\begin{array}{l}\text { ALL ENVIRONMENTAL AND } \\
\text { VEGETATION INDICES } \\
\text { Cluster and NMDS } \\
\text { (Bray-Curtis distance) }\end{array}$}} \\
\hline $\begin{array}{l}\text { Analysis } \\
\text { (Method) }\end{array}$ & \multicolumn{2}{|c|}{$\begin{array}{l}\text { Cluster (Jaccard } \\
\text { coefficient) }\end{array}$} & \multicolumn{2}{|c|}{$\begin{array}{l}\text { NMDS } \\
\text { (Bray-Curtis } \\
\text { distance) }\end{array}$} & & \\
\hline \multirow{2}{*}{ ANOSIM } & $\mathrm{R}$ & 0.01911 & $\mathrm{R}$ & 0.0509 & $\mathrm{R}$ & 0.0687 \\
\hline & $\mathrm{p}$ & 0.7949 & $p$ & 0.1805 & $p$ & 0.1318 \\
\hline \multirow{2}{*}{ NPMANOVA } & $F$ & 1.607 & $\mathrm{~F}$ & 1.607 & $\mathrm{~F}$ & 1.9710 \\
\hline & $p$ & 0.2100 & $\mathrm{p}$ & 0.213 & $\mathrm{p}$ & 0.1643 \\
\hline
\end{tabular}




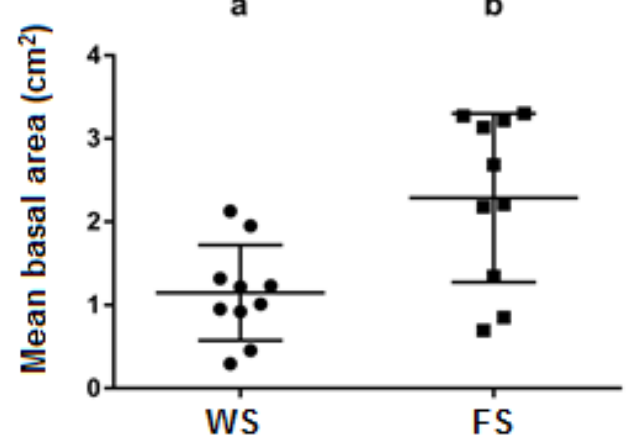

a

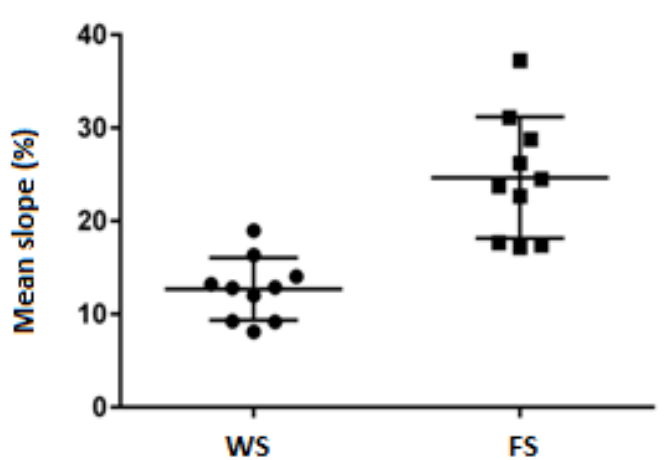

a

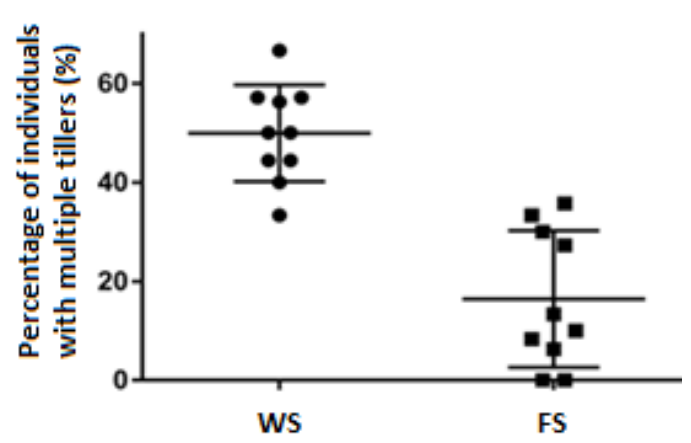

a

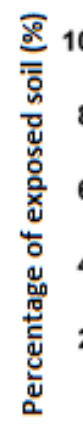

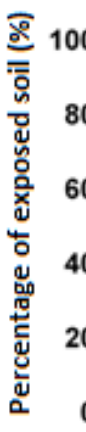

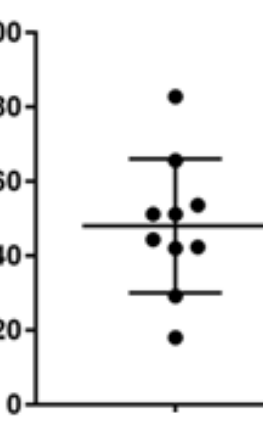

WS b

FS

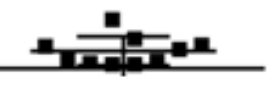

Figure 3: $t$ and $U$ tests for indexes with significant differences between WS and FS. 3a) Mean basal area $\left(\mathrm{cm}^{2}\right)$, a difference of $1.141 \pm 0.3682 \mathrm{~cm}^{2}$ was recorded between the WS (mean basal area $\left.=1.148 \pm 0.1815 \mathrm{~cm}^{2}\right)$ and FS $\left(2.289 \pm 0.3204 \mathrm{~cm}^{2}\right)$ plots: $\left.p=0.0062(<\alpha=0.05) .3 b\right)$ Percentage of individuals with multiple regrowth tillers (\%), a difference of $33.52 \pm 5.35 \%$ was recorded between the WS (mean $=49.94 \pm 3.09 \%)$ and FS $(16.42 \pm 4.37 \%)$ plots: $p<0.0001 .3 c)$ Mean slope (\%), a difference of $11.97 \pm 2.31 \%$ was recorded between the WS (mean slope = $12.69 \pm 1.06 \%)$ and FS $(24.66 \pm 2.06 \%)$ plots: $p<0.0001$. 3d) Percentage of soil exposed (\%), a difference of $44.0 \%$ was recorded between the WS (median $=47.8 \%$ ) and FS (3.8\%) plots: $p<0.0001$. Different letters above columns indicate a significant difference between samples. Tijuca National Park, Rio de Janeiro, RJ. 2015.

Figura 3: Testes $t$ e U para os índices com diferenças significativas entre WS e FS. 3a) Área basal média $\left(\mathrm{cm}^{2}\right)$, foi registrada uma diferença de $1.141 \pm 0.3682 \mathrm{~cm}^{2}$ entre as parcelas WS (área basal média $\left.=1.148 \pm 0.1815 \mathrm{~cm}^{2}\right)$ and FS $\left(2.289 \pm 0.3204 \mathrm{~cm}^{2}\right): p=0.0062(<\alpha=0.05)$. 3b) Porcentagem de indivíduos com múltiplos perfilhos (\%), foi registrada uma diferença de $33.52 \pm 5.35 \%$ entre as parcelas WS (média $=49.94 \pm 3.09 \%$ ) e FS $(16.42 \pm 4.37 \%$ ): $p<0.0001$. 3c) Declividade média (\%), foi registrada uma diferença de $11.97 \pm 2.31 \%$ entre as parcelas WS (declividade média $=12.69 \pm 1.06 \%$ ) e FS $(24.66 \pm 2.06 \%): p<0.0001 .3 d$ ) Porcentagem de solo exposto (\%), foi registrada uma diferença de $44.0 \%$ entre as parcelas WS

(mediana $=47.8 \%$ ) e FS (3.8\%): $p<0.0001$. Letras diferentes sobre as colunas indicam diferenças significativas entre as amostras. Parque Nacional da Tijuca, Rio de Janeiro, RJ. 2015. 


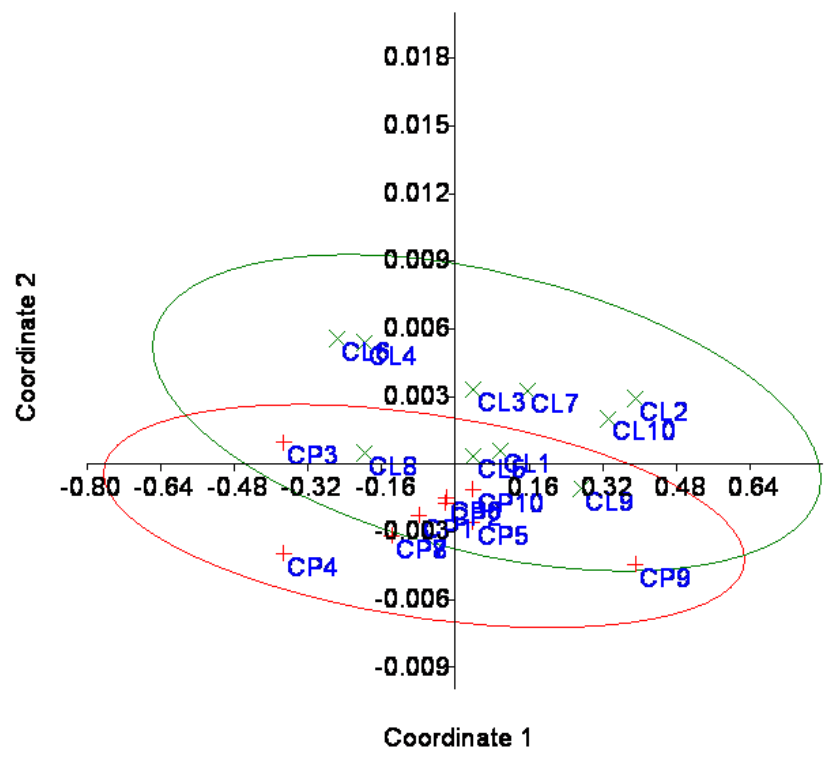

Figure 4: Two-dimensional NMDS of the euclidian distances among the WS sample (red, codified as $\mathrm{CP}$ in the image) and the FS sample (green, codified as CL in the image) comparing the morphological parameters of the vegetation. Stress $=0.002946$. Tijuca National Park, Rio de Janeiro, RJ. 2015 .

Figura 4: NMDS em 2D da Distância Euclidiana entre o conjunto WS (vermelho, codificado como CP na imagem) e o conjunto FS (verde, codificado como CL na imagem), considerando os parâmetros morfológicos. Estresse=0.0029. Parque Nacional da Tijuca, Rio de Janeiro, RJ. 2015

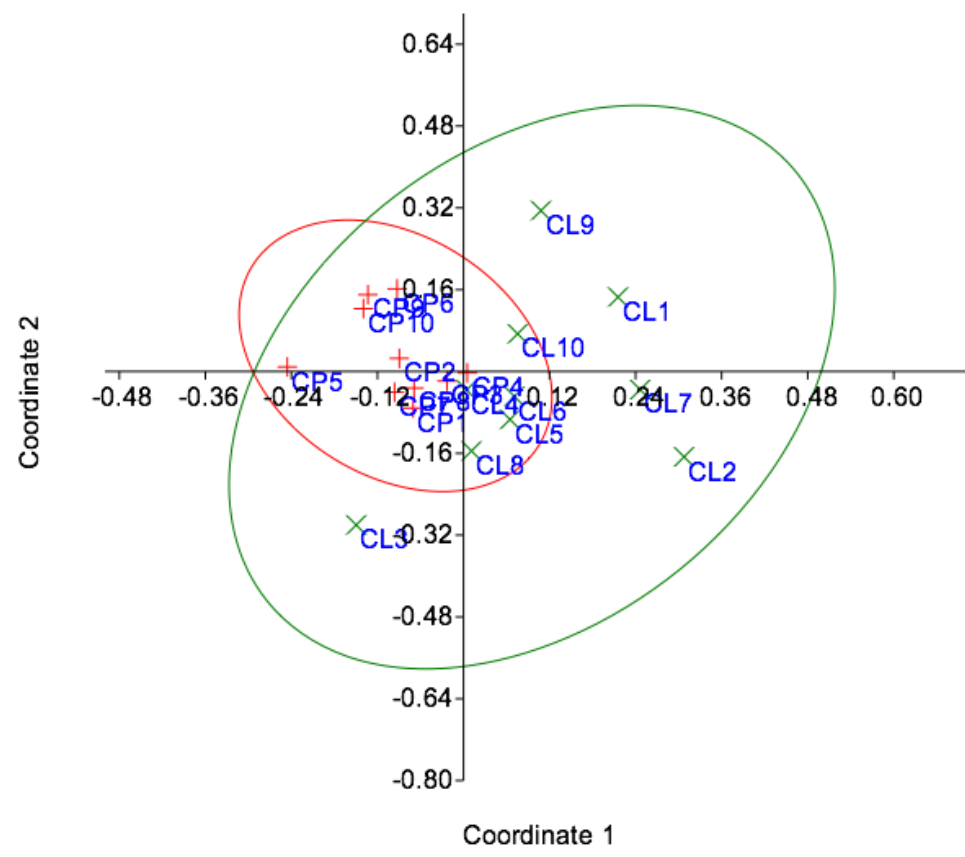

Figure 5: Two-dimensional NMDS of the euclidian distances among the WS sample (red, codified as $\mathrm{CP}$ in the image) and FS sample (green, codified as CL in the image) comparing the occurrence of species in the plots. Stress $=0.2127$. Tijuca National Park, Rio de Janeiro, RJ. 2015.

Figura 5: NMDS em 2D da distância euclidiana entre o conjunto WS (vermelho, codificado como CP na imagem) e o conjunto FS (verde, codificado como CL na imagem), considerando a ocorrência de espécies nas parcelas. Estresse = 0.2127. Parque Nacional da Tijuca, Rio de Janeiro, RJ. 2015. 


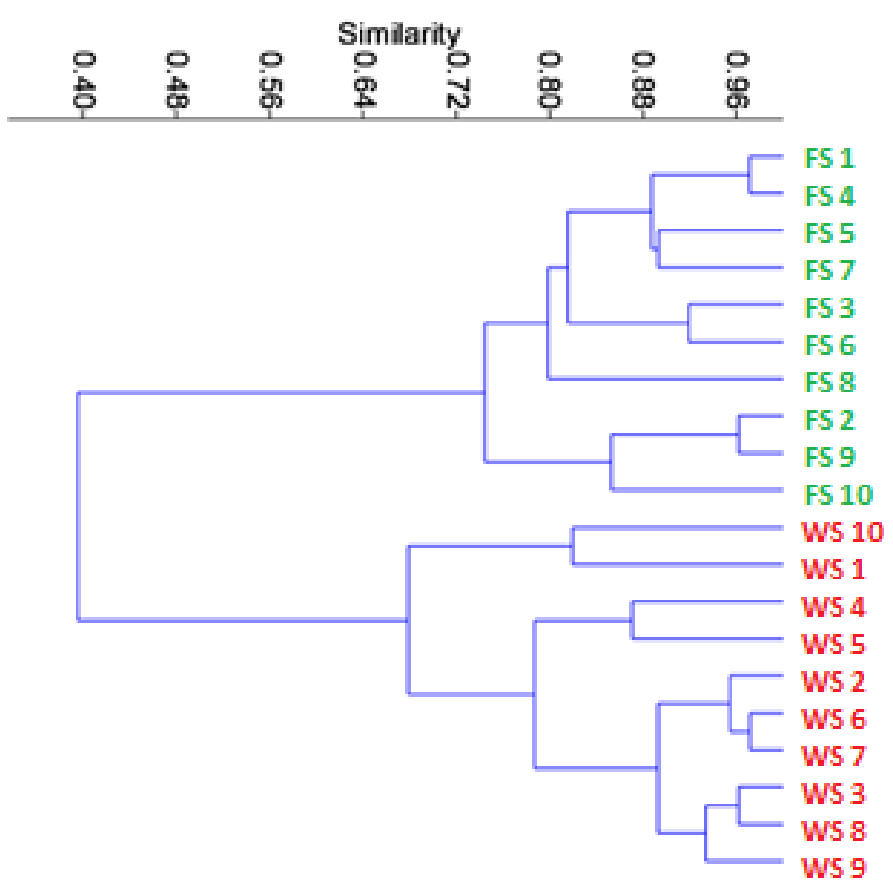

Figure 6: Cluster analysis of the Bray-Curtis distances among the FS (green) and WS (red) plots considering slope (\%) and soil exposed (\%). CCC = 0.9113. Tijuca National Park, Rio de Janeiro. 2015.

Figura 6: Análise de agrupamento com a Distância de Bray-Curtis entre as parcelas WS (vermelho) e FS (verde), considerando declividade (\%) e proporção de solo exposto (\%). CCC=0.9113. Parque Nacional da Tijuca, Rio de Janeiro, RJ. 2015.

The two samples presented a distinct species composition, as indicated by the analyses of dominance of the IVI, and the ANOSIM and NPMANOVA. All these indices indicated a higher diversity in the forest (FS) plots in comparison with the waterfall (WS) plots. This indicates the effects of the disturbance of the habitat by visitation, which would presumably be more intense closer to the waterfalls. However, the differences found in the physical characteristics of the plots, such as slope, soil exposure, and other variables not analyzed in the present study (e.g., luminosity and proximity of the water table) may also have played a role and would require further, more detailed analyses. This would help confirm whether and to what extent anthropogenic impacts influence the differences between the areas, and the contribution of physical environmental variables.

The percentage of soil exposed, which was considerably higher in the proximity of the waterfalls, where the slope was less pronounced, reflects a greater degree of degradation from the impoverishment of the soil resulting from the reduced incorporation of organic matter. This may have a negative influence on the establishment and growth of plants, reducing plant biomass, affecting primarily the species less tolerant of disturbance (ABELLAN, 1998). This situation would be exacerbated by the loss of species (GUERREROCAMPO; MONTSERRAT MARTÍ, 1996; BRAUN-BLANQUET, 1979; GUARDIA; NINOT, 1992) and the reduced development of the individuals in the regenerative stratum. 
Overall, a tendency for a reduced morphostructural development of the regenerative stratum of the vegetation was observed in the proximity of the waterfalls and the river, reflected in the significant differences found between the samples (WS and FS) in basal area and the percentage of individuals with multiple regrowth tillers, which indicate anthropogenic disturbance. A reduction in canopy cover, associated with a reduced basal area, has been linked to an increased flux of visitors in studies of impact on the vegetation (ABELLAN, 1998). The higher percentage of regrowth tillers recorded in the waterfall plots may also be related to accidental breakage caused by the greater flux of hikers and bathers moving through the area near the river, in comparison with the forest plots, which are more isolated and less accessible.

\section{Final considerations}

The multivariate analyses indicate a greater homogeneity in the structure and composition of the vegetation adjacent to the river (WS), which suggests a process of simplification of the plant community in response to anthropogenic degradation. Further, more detailed, long-term research will be necessary, however, to confirm this hypothesis. In particular, a longer-term sample would permit the confirmation, or otherwise, of the patterns observed in the present, short-term study. A number of additional parameters could be analyzed. One is the spatial distribution of species in relation to physical parameters, and a more systematic evaluation of the vulnerability of the species to direct human interference, such as trampling, breakage, the soil exposure, and related effects, may also provide important insights. Additional biological and physical indices could also contribute to a more systematic understanding of the effects of the observed anthropogenic impacts. In addition to increasing the area sampled, the detailed mapping of trails, and the more systematic analysis of the canopy, additional research could also include the experimental fencing-off and monitoring of some areas near the waterfalls. This would provide a direct, comparative measure of the indices variation in the absence of anthropogenic effects.

\section{References}

ABELLAN, M. A. Estudio del impacto ambiental causado por el recreo en los Chorros del río Mundo (Albacete) y proposición de medidas correctoras. Cuenca: Ediciones Universidad de Castilla-La Mancha, 1998, 249p.

BARLOW, J. et al. Quantifying the biodiversity value of tropical primary, secondary, and plantation forests. PNAS, v. 104, n. 47, p.18555-18560, 2007.

BRAUN-BLANQUET, J. Fitosociología. Bases para el estudio de las comunidades vegetales. Madrid: H. Blume Eds., 1979. 820p.

BUDOWSKI, G. Distribution of tropical American rain forest species in the light of successional processes. Turrialba, v.15, n.1, p.40-42, 1965. 
CAIAFA, A.N.; MARTINS, F.R. Forms of rarity of tree species in the southern Brazilian Atlantic rainforest. Biodiversity_and Conservation, v.19, n.9, p. 2597-2618, 2010.

CAMPBELL, D.G. Scale and Patterns of Community Structure in Amazonian Forests. In: EDWARDS, P.J.; MAY, R.; WEBB, N.R. (ed.) Ecology and conservation biology. Oxford: Blackwell, 1994.

DOUROJEANNI, M.J.; PÁDUA, M.T.J. Biodiversidade: a hora decisiva. Curitiba: UFPR, 2007, 282p.

GÓMEZ-LIMÓN, J.; GARCÍA VENTURA, D. Capacidad de acogida de uso público en los espacios naturales protegidos. [S.I.]: Organismo Autónomo Parques Nacionales, 2014. 89p. (Cuadernos de La Red De Parques Nacionales).

GÓMEZ-LIMÓN, J.; DE LUCIO, J. V. Recreational activities and loss of diversity in grasslands in Alto Manzanares Natural Park, Spain. Biological Conservation, v. 74, p. 99-105, 1995.

GOOGLE. Google Earth. Version 7.0 beta. 2017. Nota (Rio de Janeiro). Disponível em: <https://www.google.es/intl/es/earth/index.html>. Acesso em: 10 de abr. 2018.

GRAPHPAD PRISM version 6.00 for Windows, GraphPad Software, La Jolla California USA, Plataforma Windows. Disponível em <http://www.graphpad.com/prism/Prism.htm>. Acesso em: 26 de jul. 2015.

GUARDIA, R.; NINOT, J.M. Distribution of plant communities in the badlands of the upper Llobregat basin (Southeastern Pyrenees). Studia Geobotanica, v.12, p.83-103, 1992.

GUERRERO-CAMPO, J.; MONTSERRAT MARTÍ, G. La vegetación de zonas erosionadas en la depresión media del ebro y en el prepirineo. Influencia de factores climáticos, topográficos y geomorfológicos en la composición florística de las comunidades vegetales. In: GRANDAL D'ANGLADE, A.; PAGÉS VALCARLOS, J. (Eds). IV Reunión de Geomorfología. O Castro: Sociedad Española de Geomorfología, 1996.

HAMMER, O.; HARPER, D. A. T.; RYAN, P. D. PAST: Paleontological Statistic software package for education and data analysis. Paleontological Eletronica, v. 4, n. 1, 2001. 9 p. Disponível em: <https://palaeoelectronica.org/2001 1/past/issue1 01.htm> Acceso em: 20 de ago. 2015.

ICMBio, INSTITUTO CHICO MENDES DE CONSERVAÇÃO DA BIODIVERSIDADE. Plano de Manejo do Parque Nacional da Tijuca. Brasilia: [s.d.] 2008. Disponível em: $<$ http://www.parquedatijuca.com.br/\#planodemanejo >. Acesso em: 15 de nov. 2015.

ICMBio, INSTITUTO CHICO MENDES DE CONSERVAÇÃO DA BIODIVERSIDADE. Sitio web. Disponível em: <http://mapas.icmbio.gov.br/i3geo/icmbio/mapa/interno/home.html?51de0fac89qf dganlshbuh67j6>. Acceso: em 14 de nov. 2017. 
ICMBio, INSTITUTO CHICO MENDES DE CONSERVAÇÃO DA BIODIVERSIDADE. Sitio web. Disponível em : <http://www.icmbio.gov.br/portal/images/stories/o-que-fazemos/ranking

visitantes PN 2012 a 2014.pdf>. Acceso: 15 de nov. 2015.

JBRJ. JARDIM BOTÂNICO DO RIO DE JANEIRO. Lista de espécies da Flora do Brasil. Disponível em: $<$ http://floradobrasil.jbri.gov.br/reflora/listaBrasil/>. Acesso em: 27 de nov. 2015.

JIMÉNEZ-VALVERDE, A.; HORTAL, J. Las curvas de acumulación de especies y la necesidad de evaluar la calidad de los inventarios biológicos. Revista Ibérica de Aracnología, v. 8, 31-XII, p. 151-161, 2003.

MACHADO, A. S. Efeitos de borda de estradas sobre a comunidade arbóreoarbustiva de um trecho urbano de Floresta Atlântica, Rio de Janeiro - RJ. 2012. 82 p. Dissertação (Mestrado em Botânica), Instituto de Pesquisas Jardim Botânico do Rio de Janeiro/Escola Nacional de Botânica Tropical, Rio de Janeiro, 2012.

MAGURRAN, A. E. Measuring Biological Diversity. Oxford: Blackwell Publishing, 2004.

MELO, A.C.G.; DURIGAN, G. Efeito de borda sobre o banco de sementes em faixa de borda de Floresta Estacional Semidecidual, SP, Brasil. Acta Botânica Brasileira, v.21, p.927-935, 2007.

OLIVEIRA-FILHO, A.T.; FONTES, M.A.L. Patterns of Floristic Differentiation among Atlantic Forests in Southeastern Brazil and the Influence of Climate. Biotropica, v.32, p.793-810, 2000.

SYLVESTRE, L.S.; ROSA, M.M.T. Manual metodológico para estudos botânicos na Mata Atlântica. Seropédica: Editora Universidade Rural, 2002.

VELOSO, H.P.; RANGEL FILHO, A.L.R.; LIMA, J.C. A. Classificação da vegetação brasileira, adaptada a um sistema universal. Rio de Janeiro: IBGE, 1991. 123 p.

ZAÚ, A.S. Composição, estrutura e efeitos de bordas lineares na comunidade arbustiva-arbórea de um remanescente urbano de Mata Atlântica no sudeste do Brasil. 2010. 229 p. Tese (Doutorado em Botânica), Instituto de Pesquisas Jardim Botânico do Rio de Janeiro/Escola Nacional de Botânica Tropical, Rio de Janeiro, 2010.

ZAÚ, A.S. Relatório Científico do Processo FAPERJ: Bioindicadores de impactos em trilhas em uma unidade de conservação de proteção integral (PARNA Tijuca), no domínio da Mata Atlântica, Relatório de pesquisa, 2014b.

ZAÚ, A.S. A conservação de áreas naturais e o Ecoturismo. Revista Brasileira de Ecoturismo, São Paulo, v.7, n.2, p.290-321, maio/jul. 2014.

ZAÚ, A.S.; FREITAS, G.P.; ODA, G.A.M. "Do visitors attract or repel vertebrates in an urban park in the Brazilian Atlantic Forest?". Revista Brasileira de Ecoturismo, v.8, n.5, nov - 2015/jan - 2016, p.543-555, 2008. 


\section{Acknowledgments}

We are grateful to ICMBio/Tijuca National Park for authorizing this research and supporting each phase of the study. We extend a special thanks to all the individuals that collaborated with the fieldwork, and contributed to the development of the study and the analyses. The authors declare that there is no potential conflict of interest in the publication of this article.

\section{Nota:}

${ }^{1}$ Autores vinculados ao Programa de Pós-Graduação em Ecoturismo e Conservação

Inés Gómez Menéndez: Universidade Federal do Estado do Rio de Janeiro, Rio de Janeiro, RJ, Brasil.

E-mail: inesgomezmenendez@gmail.com

Link para o currículo Lattes: http://lattes.cnpq.br/1018144415966264

André Scarambone Zaú: Universidade Federal do Estado do Rio de Janeiro, Rio de Janeiro, RJ, Brasil.

E-mail: andrezau@unirio.br

Link para o currículo Lattes: http://lattes.cnpq.br/9561885200662079

Richieri Antônio Sartori: Pontifícia Universidade Católica do Rio de Janeiro, Rio de Janeiro, RJ, Brasil.

E-mail: richierisartori@puc-rio.br

Link para o currículo Lattes: http://lattes.cnpq.br/8540938164330840

Data de submissão: 28 de maio de 2018

Data de recebimento de correções: 24 de julho de 2018

Data do aceite: 24 de julho de 2018

Avaliado anonimamente 